\title{
Vibrational Properties Calculation of Various Modeled Bacteriochlorophyll-a Molecules
}

\author{
Dhaniram Acharya and Hari Prasad Lamichhane* \\ Central Department of Physics \\ Tribhuvan University, Kirtipur, Kathmandu, Nepal \\ *E-mail:- hlamichhane1@gmail.com
}

\begin{abstract}
Density functional theory has been used to calculate normal mode infrared stretching vibrational frequencies and intensities of neutral as well as cationic modeled bacteriochlorophyll molecules. For bacteriochlorophyll-a, the calculated IR absorption band position for neutral and cation states of Bchl-a and Bchl-a $\mathrm{a}_{2}$ structures have well matched with the published experimental results. Bacteriochlorophyll models having $13^{3}$-ester $\mathrm{C}=\mathrm{O}$ and $13^{1}$-keto $\mathrm{C}=\mathrm{O}$ have both symmetric as well as antisymmetric vibration in neutral state. Symmetric mode of vibration has higher frequency and lower intensity whereas antisymmetric mode has slightly lower in frequency and higher in intensity. However, in cation formation, the $13^{1}$-keto and $13^{3}$-ester vibrations decoupled and $13^{1}$-keto mode has higher frequency having intensity nearly double than that of $13^{3}$-ester $\mathrm{C}=\mathrm{O}$ mode. This observation of frequency upshift and IR intensity change of various carbonyl groups of Bacteriochlorophyll- $\mathrm{a}_{4}$ model molecule upon cation formation is a strong reasoning to explain the experimental difference spectra of bacteriochlorophyll-a dimer in purple bacteria reaction centre (Leonhard \& Mantele, 1993, Breton et al. 1999).
\end{abstract}

Keywords: Bacteriochlorophyll-a, Keto vibrations, Ester vibrations, IR Spectroscopy

\section{INTRODUCTION}

Bacteriochlorophyll-a molecules are mainly found in the reaction center of purple bacteria and green sulfur bacteria. They play important role in electron and proton transfer processes that occur in anaerobic photosynthesis (Scheer 1991). In aerobic photosynthesis, there exist a coordination between both Photo System II (PS II) and Photo System I (PS I) and the processes occur serially one after another but in anaerobic photosynthesis either PS II or PS I is present (Barber 1992).

In purple bacteria, bacteriochlorophyll-a molecules are bounded by groups of protein sub units. Thus, the fourier transform infrared(FTIR) absorption contains information not only from Bchl-a molecules but also from the rest of molecules present in the sample. Bacteriochlorophyll-a, pheophytin, $\mathrm{Q}_{\mathrm{A}}$ and $\mathrm{Q}_{\mathrm{B}}$ molecules undergo change in their electronic state upon cation formation but using experimental techniques for example, the FTIR difference spectroscopy, one can extract the vibrational information about Bchl-a molecule only (Masaki et al. 2015). FTIR difference spectra (DS) analysis gives rise to accurate information of the Bchl-a molecules (Lamichhane, 2011, Wang et al. 2007, Bandaranayake et al. 2006).

In the purple bacteria reaction center, the main pigment of the photosynthesis is the dimeric form of Bchl-a molecules. Being calculation of the vibrational properties of dimeric form is computationally expensive, calculations are first done in monomeric form and the results are compared with the experimentally observed data (O'Malley 2000). If the results match the trend of the dimeric form, then it can be generalized in dimeric form (Wang et al. 2007, Parameswaran et al. 2008).

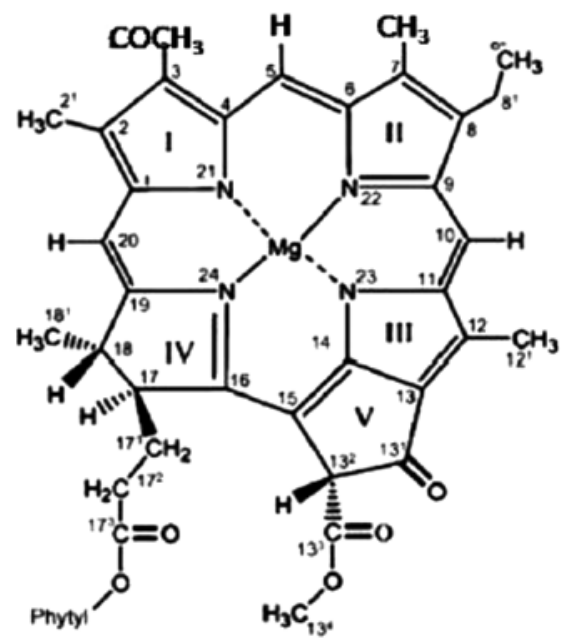

Fig. 1. Structure and IUPAC numbering scheme of bacteriochlorophyll-a

The molecular structure of Bchl-a is shown in Fig. 1 (Ke 2001). It contains $\mathrm{Mg}$ at the center of the molecules 
surrounded by four nitrogen atoms and four carbonyl groups at the $3^{1}, 13^{1}, 13^{3}$ and $17^{3}$ positions. Magnesium ion at the center of the structure is hydrophilic in nature and make the atom ionic and side carbonyl are hydrophobic in nature and make the atom polar (Sumanta et al. 2014). Side groups and phytyl tail are removed for simplicity.

In purple bacteria difference spectra, neutral band and cation band of keto mode is found respectively at 1682 $\mathrm{cm}^{-1}$ and $1702 \mathrm{~cm}^{-1}$. Similarly, neutral band and cation band of ester mode is found respectively at $1736 \mathrm{~cm}^{-1}$ and $1748 \mathrm{~cm}^{-1}$. During cation formation, intensity of keto mode is downshifted and ester mode is upshifted (Leonhard \& Mantele 1993). So, for the better understanding of these vibrational properties, we have carried out the computational method.

\section{COMPUTATIONAL METHOD}

Geometrical optimization and vibrational mode analysis of various modeled bacteriochlorophyll-a (Bchl-a) molecules were performed using hybrid density functional theory (DFT) method within Gaussian $03 \mathrm{~W}$ (Frisch et al. 2004). The functional B3LYP along with basis set 6-31 G(d) were employed for all the calculations. The International Union of Pure and Applied Chemistry (IUPAC) numbering scheme is used throughout this manuscript. Bchl-a model molecules were constructed directly using the software Gauss View 4.1. The simplest of the Bchl-a molecules which has keto groups at $13^{1} \mathrm{C}$ and $3^{1} \mathrm{C}$ positions and all other substituents of the tetrapyrrole rings are replaced with hydrogen $(\mathrm{H})$ atoms is called Bchl-a ${ }_{1}$ (Fig. 2(A)).

To further investigate possible effects due to coupling of the $\mathrm{C}=\mathrm{O}$ groups, we have also studied the second Bchl-a model, called Bchl-a that contains the $13^{1}$-keto $\mathrm{C}=\mathrm{O}$ group as well as the $17^{\frac{2}{3}}$-ester $\mathrm{C}=\mathrm{O}$ group but lacks the $13^{3}$-ester $\mathrm{C}=\mathrm{O}$ group in addition to $3^{1} \mathrm{C}$ keto group (Fig. 2(B)). The third Bchl-a model studied, Bchl-a (Fig. 2(C)) contains the $13^{1}$-keto as well as the $13^{3}$-ester $\mathrm{C}=\mathrm{O}$ groups but lacks the $17^{3}$-ester $\mathrm{C}=\mathrm{O}$ group. $\mathrm{Bchl}-\mathrm{a}_{3}$ allows the study of the coupling between the $13^{1}$-keto and the $13^{3}$-ester $\mathrm{C}=\mathrm{O}$ groups without interference from the $17^{3}$-ester $\mathrm{C}=\mathrm{O}$ group. Finally, Bchl-a ${ }_{4}$ (Fig. 2(D)) contains the $13^{1}$-keto $\mathrm{C}=\mathrm{O}$ as well as the $13^{3}$ and $17^{3}$-ester $\mathrm{C}=\mathrm{O}$ groups.

We have first tabulated the complete set of calculated normal mode vibrational frequencies and intensities for Bchl-a $\mathrm{a}_{1}$. Then we have undertaken calculations using more realistic Bchl-a models that contain two or all three of the $\mathrm{C}=\mathrm{O}$ groups. From the calculated harmonic vibrational mode frequencies and intensities, we have been able to construct IR spectra by convolving these stick spectra with a Gaussian function of $4 \mathrm{~cm}^{-1}$ bandwidth which are more realistic IR absorption spectra. Finally, we compute cation minus neutral infra-red difference spectra (IR DS) for all the Bchl-a model molecules.

\section{RESULTS AND DISCUSSION}

Calculated vibrational properties of several model Bchl-a molecules are presented here. Among four modeled bacteriochlorophyll-a molecules the first model bacteriochlorophyl-a molecule, Bchl-a ${ }_{1}$ contains only the $13^{1}$-keto group attached directly to the tetrapyrole ring and hence its mode of vibration will be the free from the coupling with other ester groups presented in the bacteriochlorophyll-a molecule.

\section{Calculation of vibrational properties of $B c h l-a_{1}$ and Bchl-a}

Bchl-a and Bchl-a have 141 and 177 normal modes of vibration respectively. Most of these modes have very low infrared intensities and are undetectable in an FTIR absorbance spectrum. For this reason, we have discussed only the most intense vibrational modes lying between $1900-1500 \mathrm{~cm}^{-1}$. Calculated vibrational mode frequencies and intensities for the most prominent modes of Bchl-a $/$ Bchl- $\mathrm{a}_{2}$ and Bchl- $\mathrm{a}_{1}^{+} / \mathrm{Bchl}_{-} \mathrm{a}_{2}^{+}$are presented in Table 1.

Fig. 3(A) shows calculated IR absorbance spectra for Bchl-a ${ }_{1}$ and Bchl-a ${ }_{1}^{+}$as well as the corresponding cation minus neutral IR absorbance difference spectra (DS) in the $1900-1500 \mathrm{~cm}^{-1}$ region. The corresponding spectra for Bchl-a $\mathrm{a}_{2}, \mathrm{Bchl}-\mathrm{a}_{2}{ }^{+}$as well as the corresponding cation minus neutral IR absorbance DS in the $1900-1500 \mathrm{~cm}^{-1}$ region are also shown in Fig. 3(B). No negative frequency of bacteriochlorophyll-a is found while calculating frequency for both neutral and cation state indicating that the molecule studied is the true energy minimized structure.

Vibrational modes frequencies are assigned by visual inspection of vibration of the molecular groups that most prominently contribute to the vibration using Gauss View 4.1 are considered. We are primarily interested in vibrational frequencies changes that occur upon radical cation. Such frequencies differences are accurately calculated without scaling. Thus, frequencies presented here are also unscaled. The most prominent band in the calculated IR absorbance spectra of Bchl-a and Bchl-a ${ }_{1}^{+}$ is the $13^{1}$-keto $\mathrm{C}=\mathrm{O}$ mode. This mode occurs at $1803 \mathrm{~cm}^{-1}$ and up-shifts $30 \mathrm{~cm}^{-1}$ to $1833 \mathrm{~cm}^{-1}$ upon cation formation (Table 1, Fig. 3(A)). The $13^{1}$-keto $\mathrm{C}=\mathrm{O}$ mode decreases in intensity by 40 percent upon cation formation (750 to $449 \mathrm{~km} / \mathrm{mol}$, Table 1). This result is good in agreement with the published experimental difference spectra of bacteriochlorophyll in $\mathrm{Rb}$. spheroids reaction center in which intense band is found at 1682/1704 $\mathrm{cm}^{-1}$ (Breton et al. 1999) and 1682/1702 $\mathrm{cm}^{-1}$ (Leonhard \& Mantele 1993). 
A

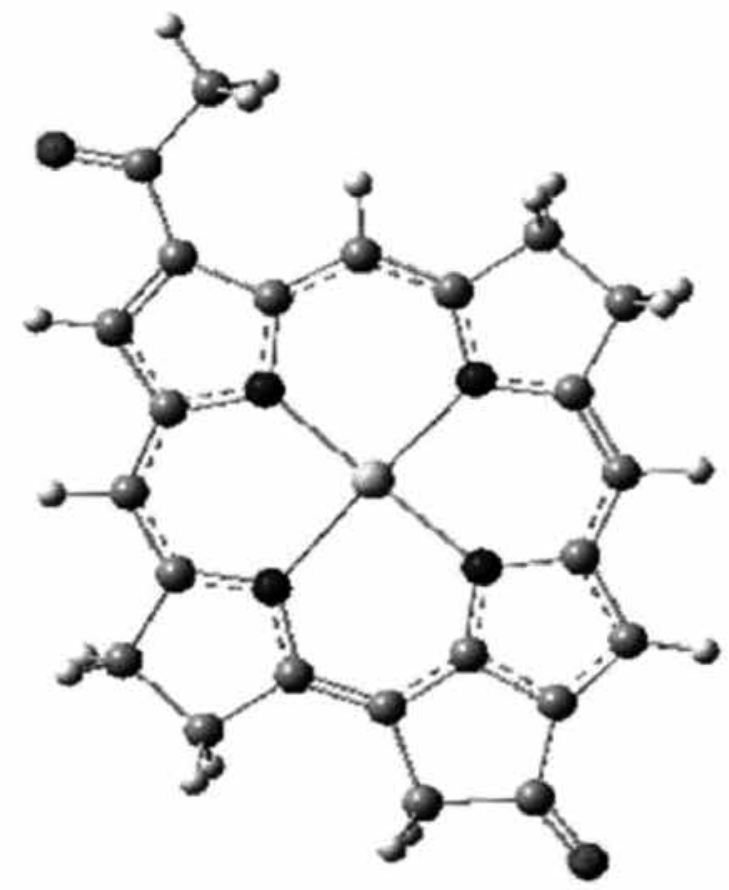

C

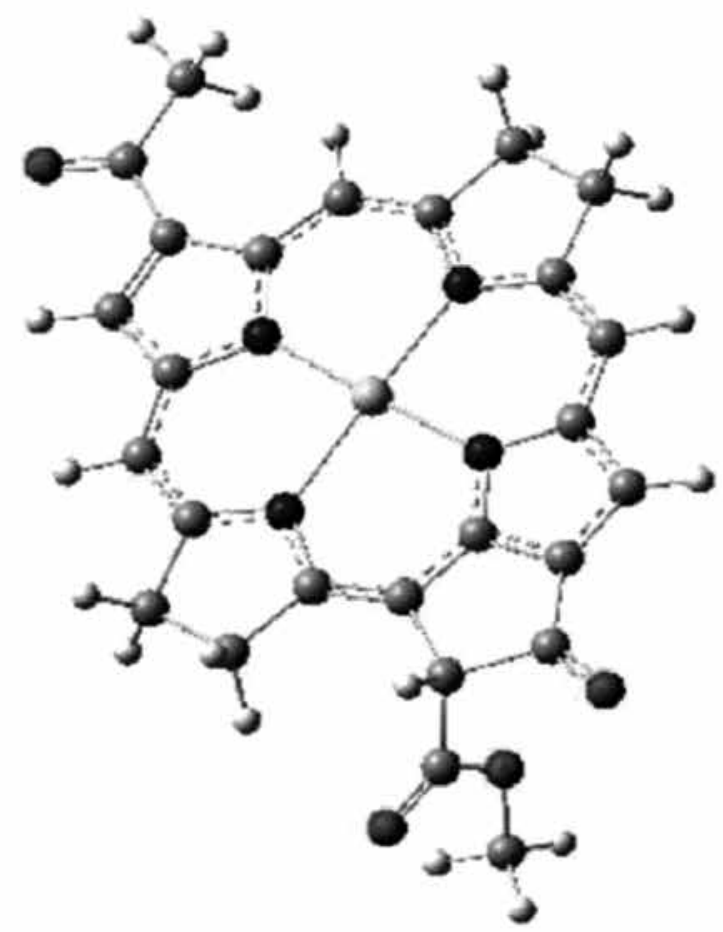

B

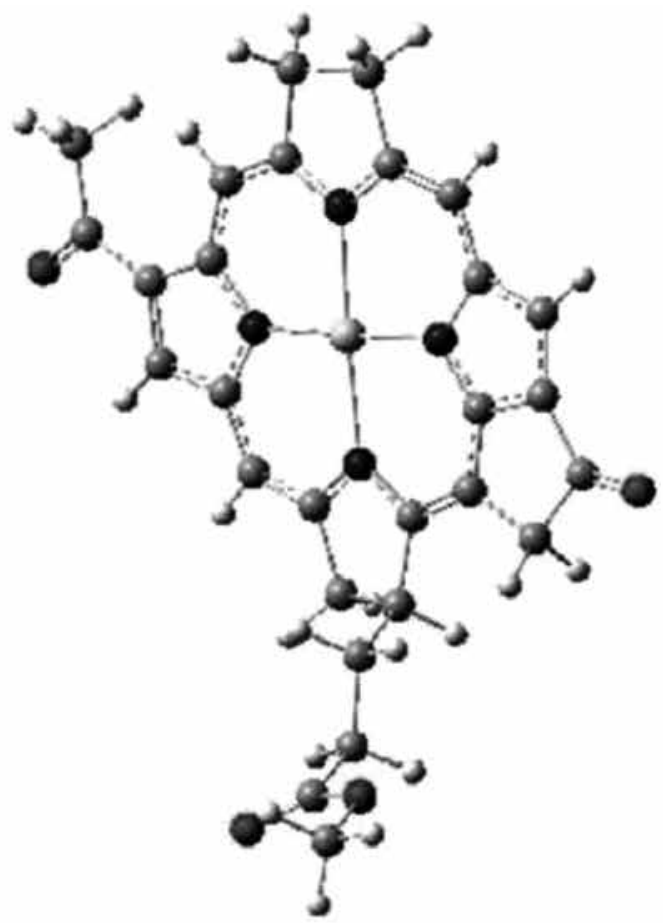

D

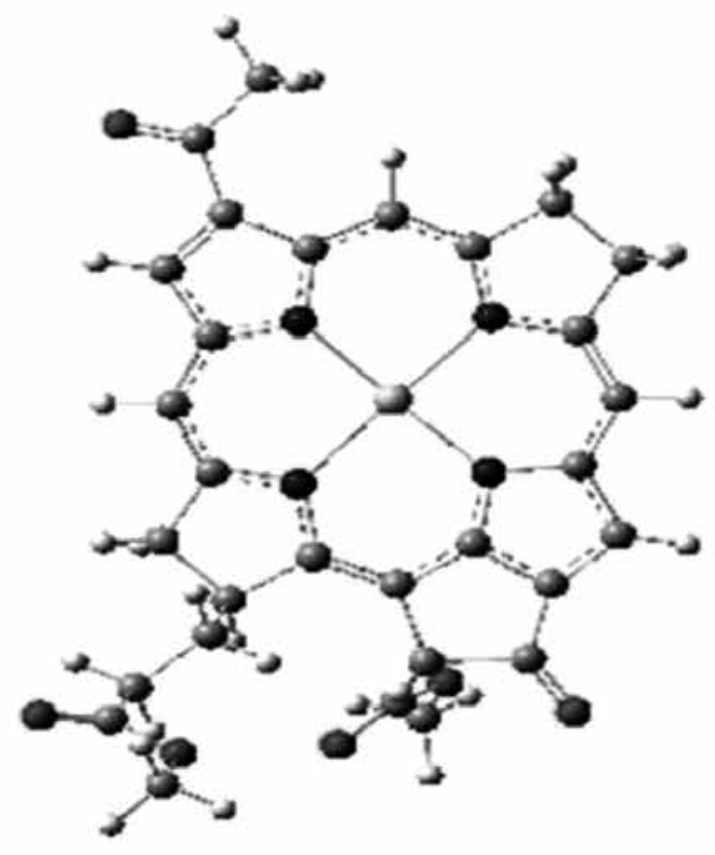

Fig. 2. Geometrically optimized (energy minimized) molecular structure of (A) BChl-a, (B) Bchl-a, , (C) Bchl-a and (D) Bchl-a ${ }_{4}$. The structures were optimized using B3LYP/6-31 G(d) method in gas phase 
Table 1. Prominent harmonic vibrational mode frequencies in $\mathrm{cm}^{-1}$ and intensities in $\mathbf{k m} / \mathbf{m o l}$ in parenthesis calculated for Bchl-a $\mathrm{a}_{1}, \mathrm{Bchl- \textrm {a } _ { 1 }}{ }^{+}, \mathrm{Bchl}-\mathrm{a}_{2}$ and Bchl- $\mathrm{a}_{2}^{+}$

\begin{tabular}{|c|c|c|c|c|}
\hline \multirow{2}{*}{ Modes } & \multicolumn{2}{|c|}{ Bchl-a } & \multicolumn{2}{c|}{ Bchl-a $_{2}$} \\
\cline { 2 - 5 } & Neutral & Cation & Neutral & Cation \\
\hline $17^{3}$-ester $\mathrm{C}=\mathrm{O}$ vibration & --- & --- & $1830(232)$ & $1841(290)$ \\
\hline $13^{1}$-keto $\mathrm{C}=\mathrm{O}$ vibration & $1803(750)$ & $1833(449)$ & $1802(740)$ & $1843(690)$ \\
\hline $3^{1}$-keto $\mathrm{C}=\mathrm{O}$ vibration & $1751(312)$ & $1781(171)$ & $1752(303)$ & $1788(279)$ \\
\hline
\end{tabular}
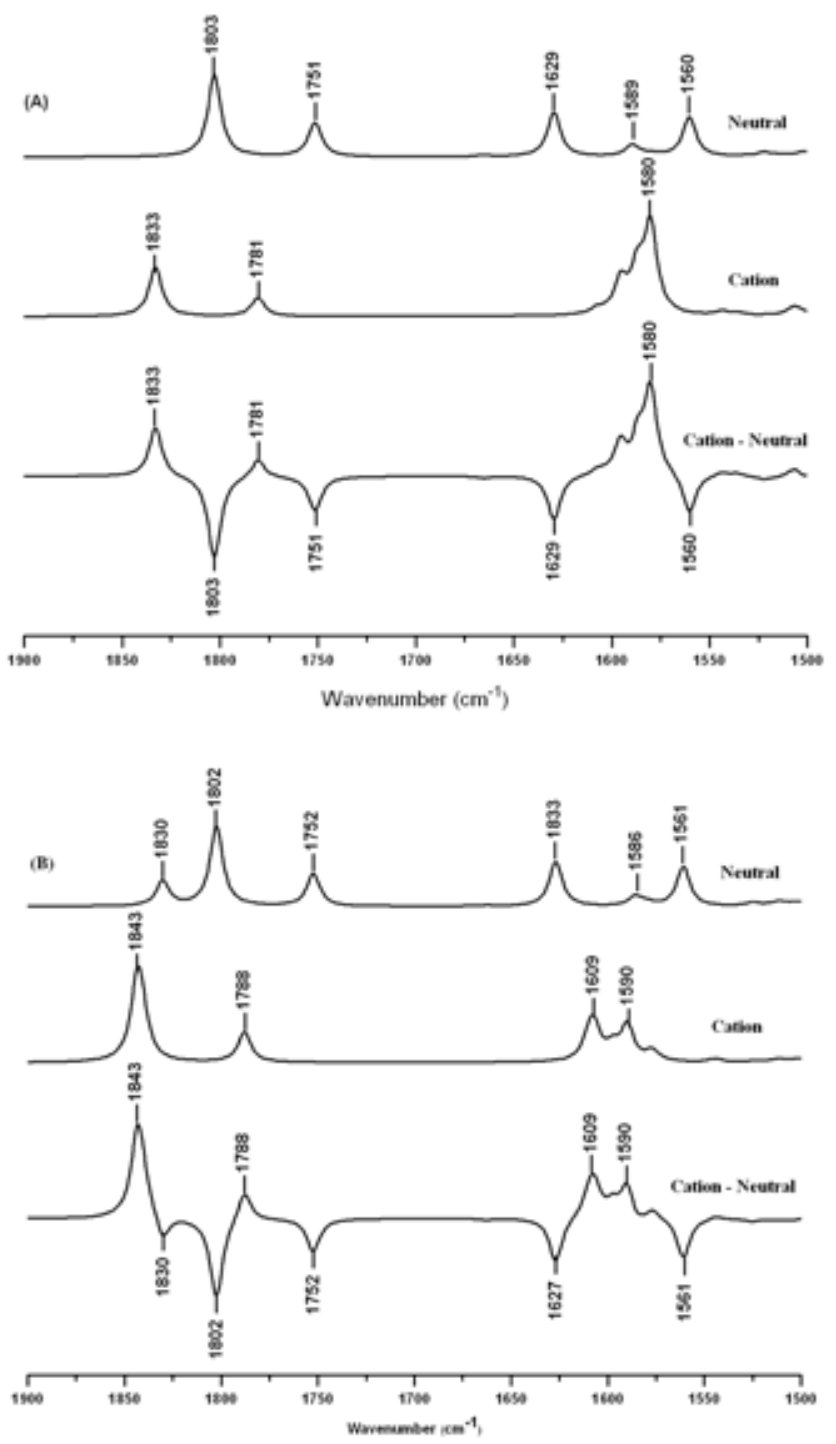

Fig. 3. Calculated IR absorption spectra of (A) Bchl-a and (B) Bchl-a $\mathrm{a}_{2}$ in the gas phase.

The neutral (top), cation (middle) and Difference (bottom) IR spectra are shown

For neutral Bchl-a ${ }_{2}$, the $13^{1}$-keto $\mathrm{C}=\mathrm{O}$ mode occurs at $1802 \mathrm{~cm}^{-1}$ and upshifts $41 \mathrm{~cm}^{-1}$ to $1843 \mathrm{~cm}^{-1}$ upon cation formation. The intensity of this mode decreases by 7 percent upon cation formation (740 to $690 \mathrm{~km} / \mathrm{mol}$, Table 1). The band frequency is same but intensity and cation induced frequency shift of the $13^{1}$-keto mode are not the same for both Bchl-a and Bchl-a $\mathrm{a}_{2}$. This result shows that presence of $3^{1}$-keto group in Bchl-a in the place of $3^{1}$-vinyl of Chl-a alters the frequency and intensity of $13^{1}$-keto group (Wang et al. 2007).

For $\mathrm{Bchl}-\mathrm{a}_{2}$, the $17^{3}$-ester $\mathrm{C}=\mathrm{O}$ mode occurs at 1830 $\mathrm{cm}^{-1}$ and up-shifts $11 \mathrm{~cm}^{-1}$ upon cation formation. Interestingly, its intensity is increased by 25 percent $(232$ to $290 \mathrm{~km} / \mathrm{mol}$, Table 1 ). It may explain the intense band at $1736 / 1748 \mathrm{~cm}^{-1}$ of experimental difference spectra of bacteriochlorophyll in $\mathrm{Rb}$. spheroids reaction center (Leonhard \& Mantele 1993). Experimentally it is seen that ester mode vibrational frequency is upshifted by $12 \mathrm{~cm}^{-1}$ and intensity is also upshifted during cation formation (Breton et al. 1999, Leonhard \& Mantele 1993). For neutral $\mathrm{Bchl}-\mathrm{a}_{2}$, the $17^{3}$-ester $\mathrm{C}=\mathrm{O}$ mode intensity is about 3 times less than that found for the $13^{1}$ keto $\mathrm{C}=\mathrm{O}$ mode (Table 1 ).

The calculated $3^{1}$-keto $\mathrm{C}=\mathrm{O}$ stretching mode of vibration of Bchl-a ${ }_{1}$ occurs at $1751 \mathrm{~cm}^{-1}$ and upshifts $30 \mathrm{~cm}^{-1}$ to $1781 \mathrm{~cm}^{-1}$ upon Bchl-a ${ }_{1}^{+}$formation for the case in which the $3^{1}$-keto $\mathrm{C}=\mathrm{O}$ lies in the plane of the macrocycle. Intensity of this mode decreases by 8 percent upon cation formation (312 to $171 \mathrm{~km} / \mathrm{mol}$, Table 1). The band associated with the $3^{1}$-keto $\mathrm{C}=\mathrm{O}$ stretch is clearly visible in the spectrum of Bchl-a ${ }_{1}^{+}$as well but it is still about 2.6 times less intense than the band associated with the $13^{1}$ keto $\mathrm{C}=\mathrm{O}$ mode (Table 1 ).

The calculated $3^{1}$-keto $\mathrm{C}=\mathrm{O}$ stretching mode of $\mathrm{Bchl}-\mathrm{a}_{2}$ occurs at $1752 \mathrm{~cm}^{-1}$ and upshifts $36 \mathrm{~cm}^{-1}$ to $1788 \mathrm{~cm}^{-1}$ upon Bchl-a ${ }_{2}^{+}$formation for the case in which the $3^{1}$-keto $\mathrm{C}=\mathrm{O}$ lies in the plane of the macrocycle. This mode is also infrared active for the neutral state but decreases in intensity by an amount of 8 percent upon cation formation (303 to $279 \mathrm{~km} / \mathrm{mol}$, Table 1). The band associated with the $3^{1}$-keto $\mathrm{C}=\mathrm{O}$ stretch is clearly visible in the spectrum of Bchl- $\mathrm{a}_{2+}$ but it is still about 2.5 times less intense than the band associated with the $13^{1}$-keto $\mathrm{C}=\mathrm{O}$ mode (Table $1)$. 
Table 2. Summary of calculated cation induced frequency shifts of the $13^{1}$-keto $C=O, 17^{3}$ - ester $C=O$ and $3^{1}$ -

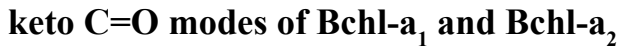

\begin{tabular}{|c|c|c|c|c|c|c|c|}
\hline \multirow[b]{2}{*}{ Molecules } & \multicolumn{2}{|c|}{ 13'-keto mode } & \multicolumn{2}{|c|}{$17^{3}$-ester mode } & \multicolumn{2}{|c|}{ 3'-keto mode } & \multirow{2}{*}{$\begin{array}{c}13^{1 / 17^{3}} \\
\text { intensity } \\
\text { (percent) }\end{array}$} \\
\hline & $\begin{array}{l}\text { frequency } \\
\mathrm{cm}^{-1}\end{array}$ & $\begin{array}{l}\text { intensity } \\
\text { (percent) }\end{array}$ & $\begin{array}{l}\text { frequency } \\
\mathrm{cm}^{-1}\end{array}$ & $\begin{array}{l}\text { intensity } \\
\text { (percent) }\end{array}$ & $\begin{array}{l}\text { frequency } \\
\mathbf{c m}^{-1}\end{array}$ & $\begin{array}{l}\text { intensity } \\
\text { (percent) }\end{array}$ & \\
\hline Bchl-a ${ }_{1}$ & +30 & -40 & --- & ---- & +30 & -45 & 319 \\
\hline Bchl-a & +41 & -7 & +11 & +25 & +36 & -8 & \\
\hline
\end{tabular}

\section{Calculation of the vibrational properties of Bchl-a $\mathbf{a}_{3}$}

For $\mathrm{Bchl}-\mathrm{a}_{3}, 13^{3}$-ester $\mathrm{C}=\mathrm{O}$ group points out of the plane of the macrocycle and slightly away from the $13^{1}$-keto $\mathrm{C}=\mathrm{O}$ group. In the detail visualization of modes of vibration of $13^{1}$-keto $\mathrm{C}=\mathrm{O}$ and $13^{3}$-ester $\mathrm{C}=\mathrm{O}$ group, we have found some coupling between them. Since their orientations are not exactly parallel to each other, coupling between them is also not strong. The presence of $3^{1}$-keto $\mathrm{C}=\mathrm{O}$ group does not have much contribution to carbonyl vibration although $3^{1}$-keto $\mathrm{C}=\mathrm{O}$ group lies in the plane of the macrocycle for both the neutral and cation species.

Bchl-a ${ }_{3}$ has 159 normal modes of vibration. Again, most of these modes are undetectable in an IR absorbance spectrum. Fig. 4 shows calculated absorbance spectra of (A) Bchl-a and (B) Bchl-a ${ }_{3}^{+}$in the $1900-1500 \mathrm{~cm}^{-1}$ region. The cation minus neutral IR DS is also shown in Fig. 4(C). Table 3 has summary of several harmonic vibrational mode frequencies and intensities and their approximate mode assignments for Bchl- $\mathrm{a}_{3}$ and Bchl- $\mathrm{a}_{3}{ }^{+}$.

For neutral $\mathrm{Bchl}_{3}$, the mode compositions are considerably more complex than that of the previous two models. In this case, $13^{1}$-keto and $13^{3}$-ester $\mathrm{C}=\mathrm{O}$ mode vibrations get mixed and the $13^{1}$-keto $\mathrm{C}=\mathrm{O}$ mode has major contribution to the anti-symmetric mode of vibration at $1805 \mathrm{~cm}^{-1}$ whereas the $13^{3}$-ester mode has major contribution to the symmetric mode of vibration at $1814 \mathrm{~cm}^{-1}$ (Table 3). From above result, it is seen that coupling between $13^{1}$-keto and $13^{3}$-ester can not be decoupled by changing side group i.e. $3^{1}$-keto in the place of $3^{1}$-vinyl group (Wang et al. 2007).

Table 3. Prominent harmonic vibrational mode frequencies in $\mathrm{cm}^{-1}$ and intensities in $\mathrm{km} / \mathrm{mol}$ in parenthesis for Bchl-a ${ }_{3}$ and $\mathrm{Bchl}-\mathrm{a}_{3}{ }^{+}$

\begin{tabular}{|c|c|c|}
\hline Modes & Bchl-a $_{\mathbf{3}}$ & Bchl-a $_{3}{ }^{+}$ \\
\hline $13^{1}$-keto $\mathrm{C}=\mathrm{O}$ only & ----- & $1835(450)$ \\
\hline$(\mathrm{C}=\mathrm{O}) \mathrm{S}$ & $1814(473)$ & ----- \\
\hline$(\mathrm{C}=\mathrm{O})$ As & $1805(570)$ & ----- \\
\hline $13^{3}$-ester $\mathrm{C}=\mathrm{O}$ only & ----- & $1819(227)$ \\
\hline $3^{1}$-keto $\mathrm{C}=\mathrm{O}$ & $1752(306)$ & $1780(170)$ \\
\hline
\end{tabular}

The antisymmetric stretching of $\mathrm{C}=\mathrm{O}$ mode of IR intensity is higher than symmetric mode at $1814 \mathrm{~cm}^{-1}$ mode (Table 3). Antisymmetric $\mathrm{C}=\mathrm{O}$ mode of neutral $\mathrm{Bchl}-\mathrm{a}_{3}$ occurs at $1805 \mathrm{~cm}^{-1}$. Upon $\mathrm{Bchl}-\mathrm{a}_{3}{ }^{+}$formation, the $\mathrm{C}=\mathrm{O}$ modes are clearly separated (Table 3 ). However, the higher frequency vibration at $1835 \mathrm{~cm}^{-1}$ is due to the $13^{1}$-keto $\mathrm{C}=\mathrm{O}$ group while the lower mode at $1819 \mathrm{~cm}^{-1}$ is due to the $13^{3}$ ester $\mathrm{C}=\mathrm{O}$ group. $13^{1}$-keto $\mathrm{C}=\mathrm{O}$ mode frequency and intensity of Bchl- $\mathrm{a}_{3}^{+}$are nearly equal to frequency and intensity of Bchl-a ${ }_{1}^{+}$but less $8 \mathrm{~cm}^{-1}$ in frequency and 35 percent in intensity than that of $\mathrm{Bchl}_{-\mathrm{a}_{2}^{+}}$.

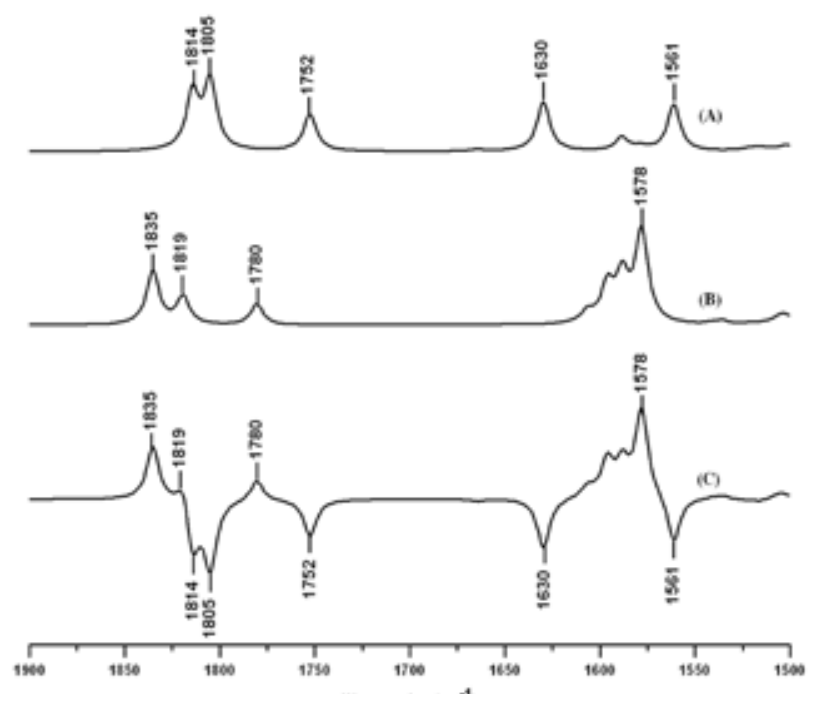

Fig. 4. Calculated IR absorption spectra for $B c h l-a_{3}$ in the gas phase. The neutral (A), cation (B) and cation minus neutral (C) IR spectra are shown

\section{Calculation of the vibrational properties of $\mathbf{B c h l - a _ { 4 }}$}

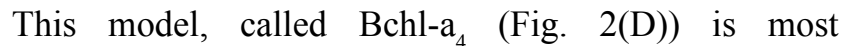
representative of Bchl-a. Fig. 5 shows calculated absorbance spectra for (A) Bchl-a ${ }_{4}$ and (B) Bchl-a ${ }_{4}^{+}$. The cation minus neutral IR DS is also shown in Fig. $5(\mathrm{C})$. For Bchl-a $\mathrm{a}_{4}$, the band at $1828 \mathrm{~cm}^{-1}$ is due only to the $17^{3}$-ester $\mathrm{C}=\mathrm{O}$ group. This mode upshifts $8 \mathrm{~cm}^{-1}$ upon cation formation and intensity changes a little. This behavior is virtually the same as that found for the same mode of Bchl-a ${ }_{2}$. This upshift is nearly equal to the 12 $\mathrm{cm}^{-1}$ upshift in the published experimental difference 
spectra of bacteriochlorophyll in Rb. spheroids reaction center of the purple bacteria (Leonhard \& Mantele, 1993). The $17^{3}$-ester group is therefore a little affected by the presence of the $13^{3}$-ester and the $13^{1}$-keto groups.

Table 4. Prominent harmonic vibrational mode frequencies in $\mathrm{cm}^{-1}$ and intensities in $\mathrm{km} / \mathrm{mol}$ in parenthesis for Bchl-a ${ }_{4}$ and Bchl-a ${ }_{4}^{+}$

\begin{tabular}{|c|c|c|}
\hline Modes & Bchl-a $_{4}$ & Bchl-a $_{\mathbf{4}}^{+}$ \\
\hline $17^{3}$-ester $\mathrm{C}=\mathrm{O}$ & $1828(236)$ & $1836(207)$ \\
\hline $13^{1}$-keto $\mathrm{C}=\mathrm{O}$ only & ----- & $1834(461)$ \\
\hline$(\mathrm{C}=\mathrm{O}) \mathrm{S}$ & $1808(338)$ & ----- \\
\hline$(\mathrm{C}=\mathrm{O}) \mathrm{As}$ & $1803(401))$ & ----- \\
\hline $13^{3}$-ester $\mathrm{C}=\mathrm{O}$ only & ---- & $1814(254)$ \\
\hline $3^{1}$-keto $\mathrm{C}=\mathrm{O}$ & $1753(298)$ & $1781(166)$ \\
\hline
\end{tabular}

As was found for Bchl-a ${ }_{3}$, the $13^{1}$-keto and $13^{3}$-ester groups are strongly coupled and unique vibrations of either $\mathrm{C}=\mathrm{O}$ groups do not exist for the neutral state. For $\mathrm{Bchl}-\mathrm{a}_{3}$, the antisymmetric vibration of $\mathrm{C}=\mathrm{O}$ groups is found to occur at lower frequency than the symmetric vibration. The intensity ratio of these two modes is also very similar to that found for Bchl-a $a_{3}$. Being the symmetric and asymmetric vibrations are right angle to each others, they do not share much of their energy during coupling. Clearly, the $17^{3}$-ester group plays no role in uncoupling the $13^{1}$-keto and $13^{3}$-ester $\mathrm{C}=\mathrm{O}$ vibrations.

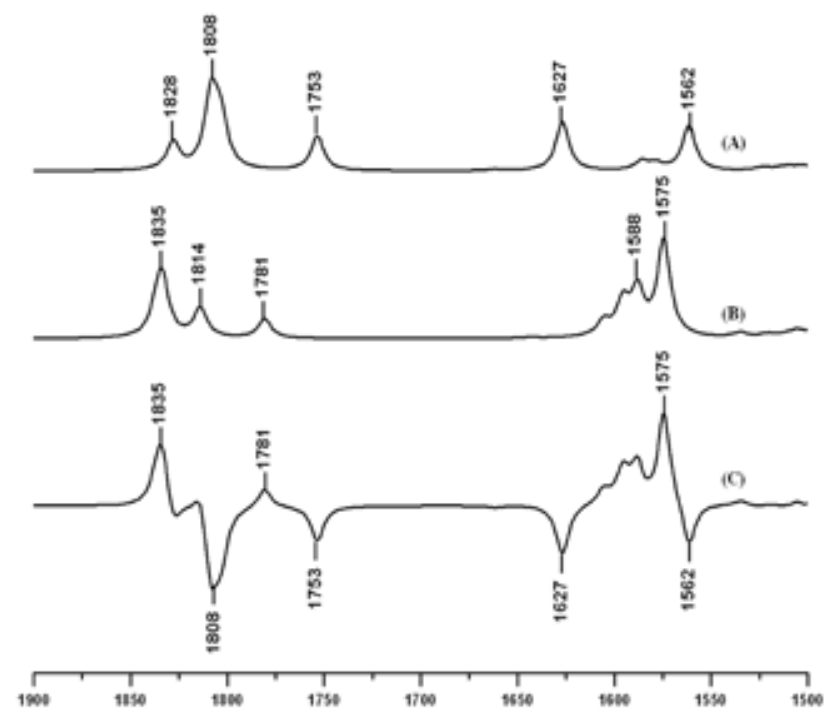

Fig. 5. Calculated IR absorption spectra for $B c h l-a_{4}$ in the gas phase. The neutral $(A)$, cation $(B)$ and cation minus neutral (C) IR spectra are shown

For $\mathrm{Bchl}-\mathrm{a}_{4}^{+}$, the $13^{1}$-keto $\mathrm{C}=\mathrm{O}$ vibration is separated from the $13^{3}$-ester $\mathrm{C}=\mathrm{O}$ vibration. Similar to $\mathrm{Bchl}-\mathrm{a}_{3}{ }^{+}$, the $13^{1}$-keto $\mathrm{C}=\mathrm{O}$ group vibrates with higher frequency i.e.
$1834 \mathrm{~cm}^{-1}$ compared to the $13^{3}$-ester $\mathrm{C}=\mathrm{O}$ group which vibrates with the lower frequency i.e. $1814 \mathrm{~cm}^{-1}$.

\section{CONCLUSIONS}

We have studied the vibrational frequency band position and IR intensities of $13^{1}$-keto group of bacteriochlorophyll in the presence or absence of $17^{3}$ and $13^{3}$-ester groups. Presence of $17^{3}$-ester has the little effect on $13^{1}$-keto while coupling is seen between $13^{3}$-ester and $13^{1}$ - keto $\mathrm{C}=\mathrm{O}$ group when $13^{3}$-ester group lie near to the $13^{1}$-keto group. It has also been seen that $13^{1}$-keto group has higher intensity among other modes. Upon cation formation, both $13^{1}$-keto mode and $13^{3}$-ester mode upshifted. The upshift of $13^{1}$-keto group is more prominent than that of $13^{3}$-ester group. The calculated frequency upshift and IR intensity change upon cation formation of Bacteriochlorophyll- $\mathrm{a}_{4}$ model molecule is affirmative to explain the experimental difference spectra of bacteriochlorophyll-a dimer in purple bacteria reaction centre (Leonhard \& Mantele 1993, Breton et al. 1999).

\section{ACKNOWLEDGEMENTS}

We are grateful to the Central Department of Physics for providing us GAUSSIAN $03 \mathrm{~W}$ software and computational facilities for our computational work.

\section{REFERENCES}

Bandaranayake, K., Sivakumar, V., Wang, R., Hastings, G. 2006. Modeling the $A_{1}$ Binding Site in Photosystem I. Density Functional Theory for the Calculation of "Anion-Neutral" FTIR Difference Spectra of Phylloquinone. Vibrational Spectroscopy 42(1): 78.

Barber, J. 1992. The Photosystems: Structure, Function and Molecular Biology, Elsevier Science Publishers.

Breton, J., Nabedryk, E., Clerici, A. 1999. Light- induced FTIR difference spectroscopy of photosynthetic charge separation between 9000 and $250 \mathrm{~cm}^{-1}$. Vibrational Spectroscopy 19: 71.

Frisch, M.J., Trucks, G.W., Schlegel, H.B., Scuseria, G. E., Robb, M.A., Cheeseman, J.R., Montgomery, Jr., J.A., Vreven, T., Kudin, K.N., Burant, J.C., Millam, J.M., Iyengar, S.S., Tomasi, J., Barone, V., Mennucci, B., Cossi, M., Scalmani, G., Rega, N., Petersson, G.A., Nakatsuji, H., Hada, M., Ehara, M., Toyota, K., Fukuda, R., Hasegawa, J., Ishida, M., Nakajima, T., Honda, Y., Kitao, O., Nakai, H., Klene, M., Li, X., Knox, J.E., Hratchian, H.P., Cross, J.B., Bakken, V., Adamo, C., Jaramillo, J., Gomperts, R., Stratmann, R.E., Yazyev, O., Austin, A.J., Cammi, R., Pomelli, C., Ochterski, J.W., Ayala, P.Y., Morokuma, 
K., Voth, G.A., Salvador, P., Dannenberg, J. J., Zakrzewski, V.G., Dapprich, S., Daniels, A. D., Strain, M.C., Farkas, O., Malick, D.K., Rabuck, A.D., Raghavachari, K., Foresman, J. B., Ortiz, J.V., Cui, Q., Baboul, A.G., Clifford, S., Cioslowski, J., Stefanov, B.B., Liu, G., Liashenko, A., Piskorz, P., Komaromi, I., Martin, R. L., Fox, D.J., Keith, T., Al-Laham, M. A., Peng, C. Y., Nanayakkara, A., Challacombe, M., Gill, P. M.W., Johnson, B., Chen, W., Wong, M.W., Gonzalez, C., and Pople, J.A. 2004. Gaussian, Inc., Wallingford CT.

Ke, B. 2001. Photosynthesis: Photobiochemistry and Photobiophysics, Kluwer Academic Publishers.

Lamichhane, H.P. 2011. Calculated Vibrational Properties of Quinones in Photosynthetic Re- action Centers, PhD Thesis. Georgia State University, USA.

Leonhard, M., Mantele, W. 1993. Fourier Transform Infrared Spectroscopy and Electrochemisty of the Primary Electron Donor in Rhodopseudomonas viridis Reation Centers: Vibrational Modes of the Pigments in Situ and Evidence for Protein and Water Modes Affected by $\mathrm{P}^{+}$Formation. Biochemistry 32: 4532.

Makita, H., Hastings, G. 2015. Directionality of electron transfer in cyanobacterial photosystem I at 298 and 77 K. FEBS Letters 589: 1412.
O'Malley, P. 2000. The Effect of Oxidation and Reduction of Chlorophyll $a$ on Its Geometry, Vibrational and Spin Density Properties as Revealed by Hybrid Density Functional Methods. Journal of American Chemical Society 122: 7798.

Parameswaran, S., Wang, R., Hastings, G. 2008. Calculation of the Vibrational Properties of Chlorophyll-a in solution. Journal of Physical Chemistry B. 112: 14056.

Scheer, H. 1991. Structure and occurence of chlorophylls, CRC Press.

Sumanta, N., Haque, C.I., Nishika, J., Suprakash, R. 2014. Spectrophotometric Analysis of Chlorophylls and Carotenoids from Commonly Grown Fern Species by Using Various Extracting Solvents. Research Journal of Chemical Sciences 4(9): 63.

Wang, R., Parameswaran, S., Hastings, G. 2007. Density Functional Theory Based Calculations of the Vibrational Properties of Chlorophyll-a. Vibrational Spectroscopy 44: 357. 